\title{
What role for local government in Sanitation promotion? Lessons from Tanzania
}

\section{Abstract}

Progress in rural access to sanitation is far behind agreed targets, especially in Sub-Saharan Africa. As a result, new policies are being defined, which shift the role of public investment from infrastructure to sanitation promotion, and give the responsibility of service delivery to local government. This paper analyzes the role that local governments can have in sanitation promotion in this new framework. The implementation of the National Sanitation Campaign in Tanzania is analyzed using the Problem Driven Governance and Political Economy methodology. Results show that direct implementation enhances local governments' commitment, but that not all functions carried out are suited to their capacities, motivations and constraints. The challenges identified emerge as a combination of technical weaknesses in the implementation of the adopted methodologies, the political economy of local governments, and the economic and social particularities of rural areas, which are similar to other countries across the region. Recommendations for a more effective service delivery model are made, balancing the role of local government between direct execution, coordination and supportive supervision. The fact of having a government programme with some direct implementation can bring about important differences in the national ownership of, and interest in rural sanitation, which are greatly needed.

Keywords : Rural Sanitation , Local Government, Policy , Governance; Political Economy, Africa, Tanzania 


\section{Introduction}

\subsection{The sanitation crisis and the paradigm shift}

Today, 2,500 million people- $35 \%$ of the world's population- do not have access to basic sanitation ${ }^{1}$.The target for Sanitation in the Millennium Development Goals, which aimed to halve the proportion of people without basic access for 2015 will not be met (WHO/UNICEF, 2012). Sanitation has been a low priority for both official development assistance (ODA) and international investments over the last decades (Jimenez and Perez-Foguet, 2009). But lack of financing is not the sole reason for the sanitation crisis. In the past, conventional public finance in sanitation had generally focused on subsidies for household and public toilets, and grants for urban sewerage and solid waste systems. Subsidies proved to be an ineffective strategy, since they failed to generate demand, do not stimulate innovation for low price products, and have not been able to address the needs of the poor; success has been limited to the amount of subsidized facilities (Cairncross et al, 2010). In addition, responsibilities in sanitation are fragmented among different sectors, which increases the complexity of public governance and the risk of administrative struggles over power and responsibility (Carlei et al 2012).The biggest deficit of access is found in the rural areas, where seven out of ten people without improved sanitation live. Of the world's regions, Sub-Saharan Africa has the lowest rural coverage of sanitation (23\%), and made the poorest progress in the last twenty years, only $4 \%$ increase in coverage (WHO/UNICEF 2012). In response to this appalling situation, sanitation has gained political momentum and 31 of the countries in the Sub Saharan region report having a rural sanitation policy drafted or gazetted in 2011 (WHO, 2012).

Two major processes emerge from those new policies: first there is a paradigm shift in the service delivery mechanisms: governments will invest in sanitation promotion (rather than in infrastructure), while the households themselves must pay for the toilet. The public officials are no longer managing substantial amounts of funds (previously subsidies) to choose some villages and provide funds for the construction of "demonstration" latrines for a number of beneficiaries; now they need to use different methodologies to raise awareness among villagers on the need to invest in sanitation, while ensuring that affordable and appropriate technical solutions are within their reach, with the support of private service providers. The type of activities carried out by the government is thus completely different, combines very different disciplines and requires different capacities in place. This shift in rural sanitation, from a public works perspective to a public health one, has in many cases led to the transfer of responsibilities between departments or even ministries. Secondly the policies have placed the greatest part of responsibility for service provision at local government level, which needs to cope with these challenges under the chronic lack of resources and qualified staff (Wunsch, 2001).

The combination of these processes (new approach, change of governmental responsibilities and decentralized service delivery) poses a formidable challenge to local governments. Despite the importance of this aspect from the practitioner's point of view, the role of local government in this new service delivery approach has received very little research attention. The recent history of the rural water sector shows us what should be avoided: over-emphasis on communities as free-standing entities, virtually ignoring the role of local government, is partly responsible for the serious

\footnotetext{
${ }^{1}$ By basic sanitation we refer to excreta disposal facilities.
} 
sustainability problem of rural water services across the region (Harvey and Reed, 2007; Jiménez and Pérez-Foguet, 2010, 2011, 2011b). Public bodies must learn to assist effectively in bringing sanitation to all (Cairncross, 2003). This paper is a step towards this learning process. The implementation of the National Sanitation Campaign (NSC) in Tanzania, a programme aimed at increasing national household sanitation coverage by $15 \%$ in three years, is used as a case study.

\subsection{The new approach in sanitation promotion}

The general failure of the previous intervention model based on public subsidies to infrastructure fostered the impulse to adopt other approaches to develop rural sanitation. Basically, two can be described (Peal et al, 2010):

- Community-wide approaches, or "total sanitation" approaches, which aim at a complete change in the behaviour of the community as a whole, and not in individual household behaviour. They are inspired in the Community-Led total Sanitation (CLTS) approach which aims to achieve and sustain an "open defecation free (ODF)" status for the community. CLTS entails the facilitation of the community's analysis of their sanitation profile, their practices of defecation and the consequences through a "triggering" exercise, leading to collective action and peer control to become ODF (Kar, 2003). It promotes community based innovation for the construction of latrines, which might not necessarily be improved ${ }^{2}$.

- Marketing of Sanitation Goods and Services, based on the social marketing concept (the use of marketing strategies and techniques to achieve a social goal). For sanitation promotion, social marketing covers both demand and supply. It sees potential sanitation users as clients who need to be motivated to invest in a latrine; and the services and products must be available at an affordable price in the right place (Cairncross, 2004).

However, these approaches are not free of challenges. Research on the results of CLTS at scale in in 18 countries of Central and West Africa show an average rate of $39 \%$ of ODF versus triggered communities (Bevan 2011), while in East Asia and Pacific a recent review over 12 countries showed a $21 \%$ of success (UNICEF, 2013). In addition, evidence from some countries shows that achieving ODF status is not a guarantee of continued use and maintenance of hygienic latrines in the long-term (Evans et al, 2009); hence, CLTS can be seen as a process to eliminate open defecation, the first step in the "sanitation ladder" (WHO/UNICEF, no date). Difficulties are also encountered with the social marketing approach. The work of the World Bank in various countries shows that the development of supply services is at least as challenging as the generation of demand (Perez et al, 2012; Pedi et al, 2012). As an example previous World Bank experience in Tanzania shows that around three-quarters of trained masons in rural areas became inactive almost immediately, around $20 \%$ were somehow active but did not have sanitation as principal income source, and below $5 \%$ of them were able to develop a sanitation business; for this they needed an "unusual mix of sales skills, technical ability, and dynamism" (Robinson, 2011).

\footnotetext{
${ }^{2}$ A sanitation facility is considered "improved" if it hygienically separates human excreta from human contact. The types of technology that are likely to meet this criterion are: flush to piped sewer system; flush to septic tank; flush to pit; composting toilet; VIP latrine; pit latrine with a slab (WHO, 2006)
} 
Some authors advocate that CLTS and marketing approaches are not only mutually compatible, but mutually complementary (Mukherjee et al, 2009). CLTS can be a powerful entry point for demand creation, which can be complemented with sanitation marketing approaches to offer villagers affordable sanitation options. The NSC in Tanzania combines these two approaches: demand is generated through CLTS techniques, while the supply of technical services would be guaranteed by supporting the development of rural private service providers (masons) for the construction of latrines.

\section{Materials and Methods}

\subsection{Analytical framework}

In recent decades, the analysis of institutions and their evolution has won the attention of some eminent scholars (e.g.: Ostrom, 2005; North, 1990). The study of public administration, though included in the broader institutional analysis, has created a distinct body of research (Ostrom and Ostrom 1971). In this context political economy studies take the existing sector context as a starting point, and aim to better understand the political and economic realities and contexts, to give specific recommendations at country and sector level (ODI, 2011). By political economy, we understand the interaction of political and economic processes in a society, the distribution of power and wealth between different groups and the processes that create, sustain and transform these relationships over time (DFID, 2009). This framework is being increasingly applied in the water supply and sanitation sector to understand barriers to progress (Swatuk, 2008; WSP, 2011; Harris et al, 2011; Hueso and Bell, 2013).

A variety of methodologies can be used for political economy analysis in the WASH sector (ODI, 2011). For our study we have used the "Problem driven governance and political economy analysis" (PGPE) methodology (Fritz et al, 2009). It is composed of three steps: i) identifying the problem, opportunity or vulnerability to be addressed, (ii) mapping out the institutional and governance arrangements and weaknesses, and (iii) identifying obstacles to progressive change and understand ing where a 'drive' for positive change could emerge.

In our case, the methodology is applied to a specific project: the National Sanitation Campaign in Tanzania. The object of analysis is the role of local government authorities (LGAs) in sanitation promotion. These LGAs are the district councils ${ }^{3}$, which are responsible for sanitation promotion according to the sanitation policy (GoT, 2011). In order to unpack the role of the district councils in the NSC, five main functions of project management have been chosen for analysis: a) Planning, b) Budgeting, c) Coordination, d) Implementation, and e) Monitoring, in coherence with the responsibilities of a district council stated in the policy ("planning, coordinating, implementing, monitoring and evaluating sanitation and hygiene activities").

Three key types of variable are commonly considered in PGPE analysis: structural factors, institutions, and actors (Fritz et al, 2009). Structural factors (the context) are beyond the direct control of the stakeholders concerned, and many such factors change only slowly over time. Under

${ }^{3}$ Mainland Tanzania is administratively divided into regions, which are composed of districts, which are divided into wards containing villages and subvillages. 
institutional variables we understand laws, and regulations, as well as informal rules; actors refer to the stakeholders who have some role or interest in the policy problem. Table 1 summarizes the methodology used, and provides detail on the specific focus of the analysis carried out for each variable. The object of PGPE analysis is to capture how these structural, institutional, and stakeholder variables interact and how they impact on the specific policy question analysed.

\section{[TABLE 1]}

Table 1. Synoptic table of the methodology used.

\begin{tabular}{ll}
$\begin{array}{l}\text { Methodology for } \\
\text { analysis }\end{array}$ & $\begin{array}{l}\text { Problem driven governance and political economy analysis } \\
\text { Object of analysis }\end{array}$ \\
& $\begin{array}{l}\text { The role of decentralized government (district authorities) in rural sanitation } \\
\text { promotion according to the new sanitation policy and the national programme } \\
\text { (National Sanitation Campaign) }\end{array}$ \\
\hline $\begin{array}{l}\text { Variables of } \\
\text { analysis }\end{array}$ & $\begin{array}{l}\text { Structural factors: i) the evolution of sanitation promotion in the country, } \\
\text { ii) the cultural values regarding sanitation among the population, and iii) } \\
\text { the traditional mechanisms in place for leadership, accountability, } \\
\text { solidarity, and collective action at village level. } \\
\text { Institutions: i) the characteristics of decentralization in place, ii) the } \\
\text { sanitation policy and allocation of responsibilities for the Campaign, iii) the } \\
\text { approach used for sanitation service delivery. } \\
\text { Actors: i) the district administration, ii) ward and village leaders, iii) village } \\
\text { committees and groups, and iv) service providers at local level. }\end{array}$ \\
\hline Processes analyzed & $\begin{array}{l}\text { Main project management functions: 1) Planning, 2) Budgeting, 3) } \\
\text { Coordination, 4) Implementation and 5) Monitoring }\end{array}$ \\
\hline
\end{tabular}

\subsection{Data collection}

The evidence of the role of local government in sanitation promotion draws from a specific information collection exercise during the first financial year of implementation of the NSC (mid 2012 to mid 2013). After an extensive review of the policy documents, grey literature and research related to sanitation in Tanzania, we obtained information about the programme at national level, through interviews with officials of the ministries concerned and key non-governmental stakeholders. The analysis of sanitation promotion activities at local level is based on the assessment of six districts (42 Districts were implementing the NSC at the time of the survey). The purposive sample included districts with an initially outstanding performance in the NSC, combined with others with regular or low performance. In each district, interviews were held with the district heads of department and the technicians dealing with sanitation issues in their daily work. Information was also collected at village level. Semi-structured interviews and group discussions were held with elected political representatives at ward, village and sub-village levels, and with governmental appointed officers at ward and village levels. The analysis of each district was completed through meetings and interviews with Non-Governmental Organizations, Community Based Organizations, village health workers, 
members of sanitation follow-up committees, local masons, and random villagers that had attended triggering sessions. The vision from the regional level was obtained through interviews in the regional secretariats. In total, 81 interviews or group discussions were carried out. Information was obtained from 3 regions, 6 districts, 9 wards and 15 villages. 12 interviews were held with institutions representative at national level, 8 at regional level, 26 at district level, and 35 at ward and village level.

All the participants were clearly informed of the purpose of the research before the interviews. All except one accepted to take part on it. Confidentiality on individual opinions was granted, in order to obtain a more sincere opinion on the challenges of the on-going process.

Most of the interviews were held in Swahili. Notes were taken during each interview and were compared within the research team before transcription. A reduced number of specialists, both practitioners and researchers, were used as key informants (Pelto, 1994).

\section{The context for sanitation in rural Tanzania}

Table 1 provides a brief description on the main topics analysed for each of the variables of the methodology used (structural, institutional, stakeholders). As these three layers of analysis overlap, results are now presented in a sequence that can facilitate its reading.

\subsection{Rural sanitation in Tanzania: history and governance}

Tanzania has a particular background as regards rural sanitation. It was promoted heavily during the 1970s, through governmental public health campaigns, that were carried out at the same time as the resettlement, often forced, of dispersed rural smallholders to "Ujamaa" villages in the rural areas. As a result, the Mtu ni Afya "campaign" managed to increase coverage significantly, but this promotion of sanitation did not change people's behaviour. Today, despite high coverage, most Tanzanian latrines are in very bad hygienic condition (Baker and Ensink, 2012). The UN Joint Monitoring Programme estimates that only $7 \%$ of the rural population in Tanzania use improved sanitation facilities, $4 \%$ share their sanitation facilities with others, $73 \%$ use unimproved sanitation facilities, and $16 \%$ of the rural population practises open defecation (WHO/UNICEF, 2012).

This poor situation has turned donors' and governments' attention to sanitation in recent years. One of the main outcomes is the elaboration of a Sanitation Policy (GoT, 2011). It is still a draft, but its contents are already guiding the sanitation promotion strategy in the country. This policy states that the ministry in charge of sanitation and hygiene issues is the Ministry of Health and Social Welfare (MoHSW), under its Environmental Health, Hygiene and Sanitation Department. The Ministry of Education and Vocational Training defines hygiene and sanitation promotion methodologies at schools, and decides on standards for school water and sanitation services. The Prime Minister's Office for Regional Administration and Local Government (PMO-RALG) is in charge of budget allocation, monitoring and supervision of Local Government Authorities. The Ministry of Water (MoW) is responsible for the Water Sector Development Plan (WSDP), which aims at raising water and sanitation coverage in the country.

The rural sanitation policy is based on each family's responsibility for provision of their own sanitation facilities ("every head of household will be responsible for promoting sanitation and hygiene in his family and ensure availability of sanitation facilities") while the district council holds 
the responsibility for "planning, coordinating, implementing, monitoring and evaluating sanitation and hygiene activities".

The operational programme of this Sanitation Policy is the National Hygiene and Sanitation Campaign (NSC), launched in 2012 for a three year period. It is aimed at ensuring that 1.3 million households improve their existing latrines or build new ones (e.g. an increase of $14 \%$ in national coverage) and the sanitation facilities of 700 schools all over the country by 2015, with an overall investment of 20 million USD. During the first financial year (2012-2013), it targeted 100,000 households in 42 districts.

The NSC will stimulate demand and improve supply through a combination of CLTS and Sanitation Marketing. The programme for sanitation promotion at household level will be delivered by training facilitators from District staff to trigger CLTS, training masons to improve available services for latrine construction and upgrades, carrying out marketing and other campaigning events and establishing a rigorous monitoring system (GoT, 2012). The approach adopted by the NSC is taken from the Total Sanitation and Sanitation Marketing project -in Tanzania (TSSM), implemented between 2009 and 2011 as part of the Global Scaling Up Rural Sanitation Project of the Water and Sanitation Program of the World Bank (http://www.wsp.org/global-initiatives/global-scaling-sanitation-project). .

\subsection{Decentralization: understanding the District Councils}

Local government in the form of devolved arms of central government was present in Tanzania even before independence. It went through different periods of recentralization, including the abolition of local government authorities in 1972, in an attempt to give power to villages; but they were reestablished in the 1980s, due in part to the failure in provision of public services (Maro, 1990). The current government's decentralization policy was outlined in the 1998 Policy Paper on Local Government Reform (GoT, 1998), which clearly sets out a policy of decentralization by devolution ('D-by- $\left.D^{\prime}\right)$. Devolution refers to a transfer of competencies from the central government to the district councils, which are distinct legal entities and should have wide autonomy.

However this decentralization has few of the attributes of autonomy and local accountability which are at the core of the rationale for it (Shah, 1998). Intergovernmental transfers represent roughly 90 percent of all local government spending (GoT, 2013), mainly to fund public services whose implementation is delegated: primary education, local health services, agricultural extension, water supply (including sanitation), and local road maintenance. In most cases, the central budget comes with specific guidelines for its use. Planning and budgeting at district level is performed through specific online software with strict central guidelines. Districts plan most of their activity on a "project basis": each project comprises a list of activities with an associated budget and very limited flexibility, that has to be approved and is controlled from central level. As a result of this, officials at District level are primarily concerned with fulfilling the requirements of line ministries, which do not incentivize cooperation between district departments nor the adoption of locally adapted initiatives. Late disbursement of funds is a common problem (GoT, 2010), which, when combined with reductions in the district's own revenues, can render a district virtually inactive.

Another key aspect of decentralization in Tanzania has been the tense relationship between district councils' technical staff and elected citizen's representatives, characterized by a mutual lack of trust (Steffensen et al, 2004). The whole district administration, including the District Executive Director, 
the Heads of Department and district's technicians are government employees. Ward and Village Executive Officers are also government workers. On the other hand, ward councillors and village and sub-village chairpersons are elected representatives. The main space of interaction of these appointed and elected groups is the District Full Council, a quarterly meeting with the presence of district heads of department and ward councillors, which in effect has a limited oversight role. Elected representatives at ward and village level have only limited impact on decision-making and implementation of plans and budgets, and virtually no power to hold district staff accountable for their performance (Venugopal and Yilmaz, 2010). This results in low downwards accountability from technical officers to local elected representatives and villagers in general.

District and regional staff are not always sufficiently committed to serve their rural citizens; they usually cite the low level of understanding and education in the community as a barrier to progress. This is also reflected at institutional level in the transfer of funds. Districts should be transferring $20 \%$ of their own revenue to the villages for development activities, but this is rarely implemented, and not monitored or enforced from national level. There is general resistance to this from the districts, which argue that the accountability mechanisms at village level are limited and there is a risk of local political interference in the use of funds.

In operational terms, per diems are probably the most important factor governing district officers' behaviour, from heads of department to technicians. Per diems are part of the government payment system: district officers receive allowances when they visit the communities, independently of the outputs produced. Allowances involve such significant amounts relative to the salary of district officials in Tanzania (Therkildsen and Tidemand 2008), that they can distort how their activities are planned and implemented (Søreide et al, 2012). The allowances system is so strongly embedded in the culture of district technicians that no visits to communities will take place if the per diem is not secured.

\subsection{The village dynamics}

Villages are grouped administratively in wards. A ward typically comprises three to five villages, and a typical district has between twenty and forty wards. Ward councillors are the main link between the population and the District Council, and are chosen in national elections. Below this level, villages and sub-villages have elected chairpersons, who are selected in local elections. These posts do not receive a monthly salary. Paid staff of the district administration are present at ward and village level (the Executive Officers), who serve as communication link between the district council and village leaders. Villages are typically organized around sectoral committees; Health, Education, Water and so on.

Village leaders are aware of the allowances system of the Government, which represents considerable amount of money compared to the average villager's income; this, added to the absence of salaries for elected representatives, explains their constant request for per diems for any activity to be carried out. Ordinary villagers are also aware of the system, being in most cases in disagreement with district officers receiving an additional payment just by "visiting the community". Villagers feel further undervalued when free work is required from them, as part of some sort of "participatory process". In the context of the villages visited, they were offered nothing or a symbolic amount (around 1/10 of the district staff allowance) for a day-'s work. Significant conflicts around allowances had already taken place between district technicians and villagers. 
Strong cohesion and peer solidarity mechanisms at community level are important for the achievement of ODF status. Since there are always vulnerable households for whom the construction of a latrine might be beyond their financial or physical capacity (e.g. elders living alone, disabled people, etc..), these safety networks are important to the success of the approach. In Tanzania, all experienced workers in the sector whom we consulted, as well as testimonies at village level affirmed that no peer solidarity mechanisms can be expected to assist vulnerable people within the communities, and that relatives (even those living outside the community concerned) constitute the safety network when someone needs specific support. Only in very exceptional cases would a person be supported with village funds or through community service work.

\section{The role of local government in the National Sanitation Campaign}

Table 2 presents our findings about the main activities carried out by each level of government in each of the main processes of the NSC. Villagers are also expected to undertake crucial activities on the process; hence an additional row for "population" has been included. - The only activity in the NSC that was planned to be outsourced outside the government was the design of campaign materials.

\section{[TABLE 2]}

Table 2. Functions at each government level in the main functions of the National Sanitation Campaign analysed

\begin{tabular}{|c|c|c|c|c|}
\hline $\begin{array}{l}\text { Level of } \\
\text { governm't }\end{array}$ & Planning \& budgeting & Coordination & Implementation & Monitoring \\
\hline National & $\begin{array}{l}\text { Select the districts } \\
\text { Define budget and } \\
\text { targets per district } \\
\text { Criteria for selection of } \\
\text { communities }\end{array}$ & $\begin{array}{l}\text { Inter-ministerial } \\
\text { coordination committees } \\
\text { Develop guidelines for } \\
\text { implementation } \\
\text { Organize national } \\
\text { trainings }\end{array}$ & $\begin{array}{l}\text { (Develop promotion } \\
\text { materials and messages) }\end{array}$ & $\begin{array}{l}\text { Collect national progress } \\
\text { data quarterly and } \\
\text { report to Donors } \\
\text { Sporadic visits to some } \\
\text { Districts }\end{array}$ \\
\hline Regional & $\begin{array}{l}\text { Plan \& budget for own } \\
\text { supervision activities } \\
\text { Collect district plans and } \\
\text { budgets }\end{array}$ & No role & $\begin{array}{l}\text { Provide technical advice } \\
\text { to Districts }\end{array}$ & $\begin{array}{l}\text { Collect regional progress } \\
\text { data quarterly } \\
\text { Regular monitoring visits } \\
\text { (Promote knowledge } \\
\text { management) }\end{array}$ \\
\hline District & $\begin{array}{l}\text { Select communities for } \\
\text { intervention } \\
\text { Make a proposal of } \\
\text { district budget and } \\
\text { activities }\end{array}$ & $\begin{array}{l}\text { (Ensure synergies } \\
\text { between actions at } \\
\text { district level) } \\
\text { Develop NSC schedule at } \\
\text { local level with wards } \\
\text { and villages }\end{array}$ & $\begin{array}{l}\text { Create awareness at } \\
\text { village level } \\
\text { Train masons } \\
\text { Purchase moulds } \\
\text { Conduct CLTS triggering } \\
\text { session } \\
\text { (Supervise masons) } \\
\text { (Organize marketing } \\
\text { events) }\end{array}$ & $\begin{array}{l}\text { Collect district progress } \\
\text { data quarterly } \\
\text { Train data takers at } \\
\text { village level } \\
\text { (Supervise } \\
\text { achievement) }\end{array}$ \\
\hline Ward & No role & No role & No role & No role \\
\hline Village & No role & $\begin{array}{l}\text { Inform people of date of } \\
\text { main meetings, } \\
\text { promoting participation }\end{array}$ & $\begin{array}{l}\text { Select data takers for } \\
\text { baseline } \\
\text { Select masons to be } \\
\text { trained } \\
\text { Select } \\
\text { committee follow-up }\end{array}$ & \begin{tabular}{lr} 
Provide & \multicolumn{2}{c}{ resources } \\
and/or transport for \\
follow-up and data \\
taking
\end{tabular} \\
\hline Population & No role & No role & $\begin{array}{l}\text { The "follow-up } \\
\text { committee" should visit } \\
\text { households regularly }\end{array}$ & $\begin{array}{l}\text { Data takers collect } \\
\text { baseline information and } \\
\text { quarterly advances }\end{array}$ \\
\hline
\end{tabular}




\section{after triggering}

Note: In brackets we represent actions that were planned but had not been carried out at the time of the survey

\subsection{Planning and budgeting}

The MoHSW selected the districts participating in the NSC for the financial year 2012-2013, set the targets per District and allocated the budget. These districts were selected on a combination of criteria, namely low coverage of sanitation, and frequent outbreaks of diarrheal diseases.

Communication to the districts concerned and main instructions were delivered through the Regional Health Officers at the regional secretariats. District Health Officers selected the target communities within their districts, following the same general criteria as used by the MoHSW. Districts did not want to choose very isolated or culturally challenging areas: they aimed at gaining confidence and experience before confronting the most difficult places. In all cases visited a balance of beneficiary communities between political constituencies was respected. The number of targeted households varied from less than 1,000 to more than 4,000 depending on the district, with an average target of 2,381 $\mathrm{HH}$ per district. The annual targets are expected to grow in the coming years, reaching on average $5 \%$ of the total population annually. The number of households covered by the NSC at District Level is higher than the target defined, since it is considered that not all of the households covered by the NSC will reach ODF status, in accordance with previous experience in the region (Bevan, 2011).

The budget per household (HH) targeted is set at 10 USD (GoT, 2012); below reference costs for Sub Saharan Africa (15 USD/HH; Hickling and Bevan,2010), and Tanzania in particular (12 USD/HH, (Malebo and Makundi, 2012). For the 2012-2013 financial year, all districts visited had received a budget between 4.5 and 5 USD/HH targeted, which is approximately half of the budget foreseen per household. An approximate $0.5 \mathrm{USD} / \mathrm{HH}$ was allocated at regional level for supervision missions. The remaining budget is presumably spent on general coordination activities at central level, but information on expenditure at central level was not available. In the first year of the NSC, funds were not ready to use until six months after the start of the financial year, due to delays in transfers from central level.

Each of the districts visited had a clear plan of activities with its associated budget. Costs at District level mainly consist of district staff allowances for each community visit ( $45 \%$ on average), and fuel (20\%). Food and refreshments for the sessions, stationary and materials (especially moulds for casting slabs) complete it. Funds to incentivize villagers for specific tasks represented between 0 and $5 \%$ of the foreseen budget in the districts visited ( $2 \%$ average). However, as shown in table 2 , villagers had been allocated crucial and time consuming activities, such as the collection of database, the follow-up of a community action plan after triggering of demand, and quarterly check on progress.

\subsection{Coordination}

An inter-ministerial Memorandum of Understanding was signed in 2010 by the four ministries involved in sanitation promotion. As result, various working groups have been organized, which meet regularly with the presence of the main non-governmental stakeholders in the sector. These working groups have not been replicated at local level, however. 
In all districts visited, District Health Departments were effectively leading the NSC. A very strong sense of ownership of the process was found, with significant engagement of the staff including the District Health Officer (DHO). In the previous financial year (2011-2012) a nationwide training event was held, where district and regional health staff had been trained in CLTS for 5 days. Adapted guidelines for CLTS triggering had also been produced and distributed. As a result of this, DHOs were relatively confident on how to do sanitation promotion.

Beyond general informative meetings, the flow of information between the Water, Education and Health departments was poor in general, as regards specific aspects where coordination could improve the impact of the programme. As a result, interventions in schools and communities often happened in different villages, or supply side activities for training masons often did not take account of previous interventions from the Water Department.

The communities selected were normally informed of their participation in the NSC through a phone call to the village authorities. None of the villages had made any previous request or action to qualify for the programme. In some places this was followed by meetings with different ward and village committees to explain the campaign and gain their support. In general, the full involvement of village and ward leaders had not been achieved, and there was room for improvement.

\subsection{Implementation}

When it comes to implementation of the activities, the responsibilities are given to the District, which in turn delegates some critical activities to villagers (see Table 2). The key messages and promotional materials for the Campaign are produced and distributed at national level, while the Region has an advisory role, reinforced by quarterly monitoring visits.

The activities which are the responsibility of the districts can be summarized as: i) Awareness creation for ward and village leaders (already commented); ii) Baseline data collection; iii) Training of masons; iv) Triggering demand through CLTS; v) Follow-up of community action plans.

The baseline data collection involved a household census with the basic data regarding sanitation and hand washing facilities, following a template developed by the MoHSW. All of the villages visited had done the baseline survey. In order to fill it, the commitment of one or two data takers per subvillage was required, selected among villagers and trained for half a day by district technicians. In some places, data takers were paid up to 15,000 TZS (10 USD) for the exercise. No help with transport was provided by the District. However, regular sub-villages can have 100 households, and some had more than 300 . Sometimes, small allowances for transport (e.g. taking a motorbike ride to one remote area) were provided by the village government. Around $25 \%$ of failure in the records was estimated by some district health workers; regional officers were supposed to check random questionnaires as part of their first monitoring visits. $40 \%$ of questionnaires checked in our survey were significantly wrong, though our sample cannot be considered as statistically representative.-

The CLTS triggering exercise was carried out by district staff, usually with the personal involvement of the DHO. Triggering was done for a whole village in one day in most of the cases. Even though the MoHSW recommendation was to do the triggering by sub-village, this was not always respected due to lack of funds to pay for related costs. It has been observed that triggering is focused on the 
improvement of latrines to specific standards ("not all latrines are valid"), consistent with the Tanzanian reality (high coverage of bad quality latrines), but different from the standard CLTS, which heavily supports local innovation and does not recommend promoting any specific type of latrine (Kar and Chambers, 2008). All communities where triggering had taken place had signed a "village declaration form to end open defecation" (as per MoHSW template), but only 20\% of the villages visited had a clear and visible community action plan that could be consulted. In about $20 \%$ of places, triggering had been suspended because of low attendance.

At the triggering session, a committee of eight villagers had been elected by the attendants to follow up the "village declaration". The main mission of this committee is to visit house by house regularly and check the progress towards ODF status. No training, support, incentives (neither in cash or kind) or transport had been provided to this committee. It was found that these committees were either inactive or performing their duties with very poor quality. No clear routine follow-up tasks could be described by those involved in the committees.

From the supply side, the activities related to selection and training of masons were weakly designed and implemented. The availability of capacities at village level was in general not taken into consideration. The strategy was to: i) train one mason per village, proposed by the village leaders, who should provide sanitation services to villagers to their demand; ii) purchase some moulds, necessary to cast concrete slabs (around 20 for each District), which would be kept at the District Council's premises and be borrowed from masons when needed. The NSC supplies these moulds since their cost (around US\$50) and the lack of availability on the local market make their purchase beyond the capacity of the majority of village masons. Follow-up and regulation of masons' activities was not perceived by district staff as part of their duties. In general, the purchase of sanitation services is considered as a free business transaction between the masons and their clients. At village level, it was found that many of the masons trained in the past did not carry out the expected activities when they came back to their villages. For all active masons met, these services did not constitute their main income generating activity. None of the masons interviewed knew where to buy a mould, or its price; nor had any intention to do that. In some cases, they had kept the moulds intended to be rotating. Masons were making the procurement of raw materials needed to fabricate slabs (cement, wire mesh, and aggregates). Most of them requested upfront payment from clients. As the cost of basic units of materials, e.g. a bag of cement, is more than the price of a slab, the potential customers had to organize themselves in groups, so that supplies could be bought by the mason without any expenditure from his side. This system creates additional difficulties for the potential clients, threatening the possibilities of success. Prices for san plat slabs were kept very affordable (US\$ 3 to 5), but in the village with highest demand, the mason had increased his price to US\$8.

\subsection{Monitoring}

District staff intended to follow up progress through mobile phone communication or taking advantage of other field trips scheduled to nearby areas. Funds were in general not enough to make specific follow-up visits. Regional Health Officers had also planned at least quarterly visits to the districts. The MoHSW was already undertaking visits to a sample of districts, checking the progress of the activities. 
As regards the recording of progress against the baseline, this is supposed to be done quarterly using the same formats and procedure as the initial data collection, with the core of the work being carried out by villagers. The information should then be further aggregated at district, regional and national level.

\section{Adjusting the role of local government}

The high degree of ownership of the process and the commitment to sanitation found in the District Health Departments has no precedent in Tanzanian local government in the last two decades. Undoubtedly, the fact of having a national programme managed and directly implemented by the Government has a positive influence. This is an important reason for keeping some direct implementation functions and the whole responsibility of the programme within district governments. The key question is, which processes can be kept within the district authorities and which ones would benefit from the involvement of other stakeholders?

The rigidity of the District budget and the important share of costs represented by staff per diems does not allow for a continuous and flexible interaction with the village level. At present, districts tend to focus their presence at village level as a one-off triggering session. As mentioned,-triggering has a positive effect on the district's ownership and commitment towards the outputs of the process and can be planned as a specific activity, which fits well with the particularities of district planning. If this continues to be the case, additional training of Districts technicians would be necessary, given the importance of very good facilitation for the success of this approach (Peal et al, 2010; Malebo and Makundi, 2012; Mukherjee, 2011). However, two important drawbacks need to be addressed. First, the behaviour change expected is essentially a community process, so that a supportive attitude from local leaders is key to success (Musyoki, 2010). Achieving this local buy-in is crucial, and district technicians are unlikely to achieve this, due to general mutual lack of trust, and insufficient funds to ensure an adequate presence and respect for village timing. Secondly, the current method leaves the bulk of post-triggering support and supervision to a village follow-up committee constituted ad hoc at the triggering session and not trained. This contrasts with some of the keys for success of the CLTS approach, which in its origins required skilled facilitators to spend a large amount of time with the villagers on a regular basis (Allan, 2003), a requirement which is confirmed in studies of more recent programmes (Bevan, 2011; Malebo and Makundi, 2012). Hence, it might be more appropriate to use existing community-based resources such as Community Based Organizations (CBO) and/or Village Health Workers (VHW) to lead the relationship with the community from the outset, including routine data collection for monitoring of progress. This would require an adequate prior training, and some kind of recognition, transport provision and monetary incentives (which can be partly based on the outputs achieved).

On the supply side, the private sector is needed for providing affordable sanitation solutions to rural households. The development of entrepreneurship in this field is far from simple, and Tanzania is no exception. Hence, in the short term, active and competent part time masons with access to the necessary materials (especially casting moulds) can be the best service to aim for in many rural areas. In order to achieve this, the selection process of candidates based on their interest, the quality of training process and providing follow-up and support in the initial stages are crucial. These functions are not at the core of health departments' capacities and also require regular on-site presence. Under these circumstances they could be better performed by vocational training institutions or 
specialized service providers. The development of local sanitation entrepreneurship should be considered within a wider Local Economic Development approach. In addition, a strategy focused on starting the latrine promotion in semi-urban villages (Jenkins and Cairncross, 2009), could help to develop an incipient private sector that could later expand to more isolated villages. The access to credit either for masons or villagers is another challenge that needs to be addressed (Tremolet et al, 2010).

With the main functions of demand generation and supply support outsourced, district governments should be responsible for the management of the whole process, with special attention to three specific aspects: quality of monitoring, equity of outputs and regulation of service providers. The capacity of the CLTS approach to reach all, mobilising community solidarity mechanisms to assist vulnerable households, has worked in some places (Harvey, 2011) but cannot be considered as the general trend (UNICEF, 2013). Moreover, some breaches of individual rights have been reported due to the social pressure of achieving ODF status at community level (Bartram et al, 2012). Hence, ensuring an adequate approach and monitoring the equity of the campaign outputs should be a core function of local government, facilitating post implementation subsidies to vulnerable households if needed. The supervision of the service providers needs also to be addressed. Regulatory options in this context should rather be along the lines of recognition, dialogue, facilitation and collaboration (Samson, 2006), as support for private sector development.

\section{Conclusions}

This paper, dealing with the challenges of local government's direct implementation of a sanitation programme, provides a context for the findings of the recent ( still unpublished) impact evaluation of its predecessor and pilot, the TSSM project implemented by the World Bank Water \& Sanitation Program in 10 districts, which found only a marginal increase, around $10 \%$, in sanitation coverage in intervention wards, and no detectable impact on open defecation, in spite of significant increases in awareness of the programme's messages.

More than that, it offers an analysis of key strengths and weaknesses of a hybrid policy approach (CLTS and Sanitation Marketing combined to deliver sanitation promotion through decentralized government) which is widespread in Sub-Saharan Africa and other regions with low sanitation coverage. This approach requires for its success the synergetic combination of very different elements: while demand creation aims at changing private behaviour and priorities through public health messages, the translation of this demand into better services requires government support and the involvement of informal service providers with rather different economic interests.

The challenges identified in the case study are the result of a combination of technical weaknesses in the implementation of the adopted methodologies, the political economy of local government, and the economic and social particularities of rural areas, which are similar to other countries across the region. Hence, many of the constraints and recommendations indicated could be taken into consideration for similar programmes in other countries.

Some of the challenges identified, such as the central control of local government or the limited accountability from these local governments towards rural villages are unlikely to change in the short term. The adjustments proposed to the role of local government (section 5) take these elements 
into consideration and are thus intended to be feasible, though are not enough to address all challenges. However, balancing the role of local government between direct execution, coordination and supervision of the sanitation promotion process could improve its outcomes significantly. These changes would require an increase in the budget (specially for village level activities), the engagement of other non-governmental stakeholders in demand and supply development, a strengthened monitoring process with a follow-up on the equity of outcomes, and the supportive regulation of service providers. Even if only modest success can be expected in the short term, the fact of having a government programme with some direct implementation, though not huge in scale, can bring about important differences in the national ownership of, and interest in rural sanitation, which are greatly needed.

In addition, there is a need to keep working on different methodologies for sanitation promotion and their minimum resource requirements, since those now being widely adopted in new national policies for demand creation and to develop supply services are encountering significant challenges when implemented at scale.

\section{Acknowledgments}

The authors would like to extend thanks to all institutions and individuals who kindly participated in this study. Financial support for this research was provided through the SHARE research consortium, funded by the UK Department for International Development, and the Beatriu de Pinos grant (BPDGR 2011), funded by the Agencia General d'Ajuts Universitaris i de Recerca -AGAUR- (Generalitat de Catalunya) and awarded to A. Jiménez. The support received from Wateraid and ONGAWA in Tanzania are also gratefully recognized. Thanks as well to Sian White, Joanna Esteves Mills and five anonymous reviewers for their valuable inputs to the first version of this article. 


\section{REFERENCES}

Allan, S.C. (2003). The WaterAid Bangladesh / VERC 100\% Sanitation Approach: Cost, Motivation and Sustainability. MSc Thesis. London School of Hygiene and Tropical Medicine, September, 2003

Baker, S.M., \& Ensink, J.H. (2012). Helminth transmission in simple pit latrines. Trans R Soc Trop Med Hyg. 106(11), 709-710. doi: 10.1016/j.trstmh.2012.08.002.

Bartram, J., Charles,K., Evans, B., O'Hanlon L., \& Pedley, S. (2012). Commentary on community-led total sanitation and human rights: should the right to community-wide health be won at the cost of individual rights?. Journal of Water and Health 10 (4).

Bevan, J. (2011). A review of the UNICEF roll-out of the CLTS approach in West and Central Africa. Proceedings of the 35th WEDC International Conference. Water, Engineering and Development Centre. Loughborough University, Loughborough, UK

Cairncross, S. (2003). Sanitation in the developing world: current status and future solutions. Internationa Journal of Environmental Health Research. 13, Iss. sup001.

Cairncross, S. (2004). The Case for Marketing Sanitation. Field Note, Water and Sanitation Program, World Bank. http://siteresources.worldbank.org/INTWSS/Resources/case_marketing_sanitation.pdf

Cairncross, S., Bartram, J., Cumming, O., \& Brocklehurst, C. (2010). Hygiene, Sanitation, and Water: What Needs to Be Done? PLoS Med 7(11): e1000365. doi:10.1371/journal.pmed.1000365.

Carlei, V., Marra, A., Pozzi, C. (2012). Public Governance, Human Capital and Environmental Outcomes: an Analysis Based on Self-Organizing Maps. Env. Pol. Gov. 22, 116-126.

Department for International Development (2009). Political Economy Analysis, How To Note. A DFID practice paper. London: Department for International Development.

Evans, B., Jones, H., Colin, J., \& Robinson, A. (2009). Sustainability and equity aspects of total sanitation programmes. A study of recent WaterAid-supported programmes in three countries: global synthesis report. WaterAid. Accessed October 1, 2013 at

http://www.indiaenvironmentportal.org.in/files/global_sythesis_report_1.pdf

Fritz, V., Kaiser K., Levy, B. (2009). Problem driven governance and political economy analysis. Good Practice Framework. The World Bank, September 2009.

Government of the United Republic of Tanzania (2010). Assessment of the effectiveness of formula based Budgetary allocation to local government Authorities (LGAs). Ministry of Finance and Economic Affairs. $\begin{array}{lccc}\text { Accessed } & \text { October } & 1, & 2013 \\ \text { http://www.tzdpg.or.tz/index.php?elD=tx nawsecuredI\&u=0\&file=uploads/media/Draft Report FBA LGAs }\end{array}$ http://www.tzdpg.or.tz/index.php?elD=tx nawsecuredl\&u=0\&file=uploads/media/Draft Report FBA LGA

Government of the United Republic of Tanzania (2011). Sanitation and hygiene policy, Draft. January 2011. Ministry of Health and Social Welfare, Dar es Salaam.

Government of the United Republic of Tanzania (1998). Local Government Reform Programme - Policy Paper on Local Government Reform,. Ministry of Regional Administration and Local Government, P.O. Box 1923 Dodoma, October 1998

Government of the United Republic of Tanzania (2012). Concept Note: National Sanitation Campaign. Ministry of Health and Social Welfare. 
Government of the United Republic of Tanzania (2013). Local Government Information Portal. Accessed October 1, 2013 at http://www.logintanzania.net/lgafinance.htm

Harris, D., Kooy, M., \& Quang, P. (2011). Scaling up rural sanitation in Vietnam: political economy constraints and opportunities. Working Paper 341. Overseas Development Institute,December 2011.

Harvey, P., \& Reed, R.A. (2007).Community-managed water supplies in Africa: sustainable or dispensable? Community Development Journal, 42 (3), 365-378.

Harvey, P. (2011).Community-led total sanitation, Zambia: Stick, carrot or balloon? Waterlines, 30(2), 95-105.

Hickling, S. , \& Bevan, J. (2010). Scaling up CLTS in sub-Saharan Africa. In Tales of shit: Community-Led Total Sanitation in Africa, vol 61. Participatory Learning and Action (PLA), London. Accessed October 1, 2013 at http://www.communityledtotalsanitation.org/resource/tales-shit-community-led-total-sanitation-africa-pla-61

Hueso, A. \& Bell, B. (2013). An untold story of policy failure: the Total Sanitation Campaign in India. Water Policy, 15 (6), 1001-1017.

Jenkins, M.W., \& Cairncross, S. (2009). Modelling latrine diffusion in Benin: towards a community typology of demand for improved sanitation in developing countries. Journal of Water \& Health 8(1),166-183.

Jiménez, A., \& Pérez Foguet, A., (2009). International Investments in the Water Sector. International Journal of Water Resources Development, 25 (1), 1-14.

Jiménez, A., \& Pérez-Foguet, A. (2010) Building the role of local government authorities towards the achievement of the right to water in rural Tanzania. Natural Resources Forum, 34, 93-105.

Jiménez, A., \& Pérez-Foguet, A. (2011) The relationship between technology and functionality of rural water points: evidence from Tanzania. Water Science and Technology, 63 (5), 949-956. DOI: 10.2166/wst.2011.274.

Jiménez, A., \& Pérez-Foguet, A. (2011b). Implementing pro-poor policies in a decentralized context: the case of the Rural Water Supply and Sanitation Program in Tanzania. Sustainability Science, 6, 37-49.

Kar, K., \& Chambers, R. (2008). Handbook on Community-Led Total Sanitation. Plan UK and Institute of Development Studies (IDS), Brighton.

Kar, K. (2003). Subsidy or Self-Respect? Participatory Total Community Sanitation in Bangladesh. Working Paper 184, Institute for Development Studies.

Malebo, H.M.,\& Makundi, E.A. (2012).Outcome and Impact Monitoring for scaling up Mtumba Sanitation and Hygiene Participatory Approach in Tanzania. Sanitation and Hygiene research for Equity (SHARE) Report, August 2012.

Maro, P.S. (1990). The impact of decentralization on spatial equity and rural development in Tanzania. World Development, 18(5), 673-693

Mukherjee, N., Kumar, A., Cardosi, J., \& Singh, U. (2009). What does it take to scale up and sustain rural sanitation beyond projects? Waterlines, 28 (4), 293-310.

Mukherjee N. (2011). Factors Associated with Achieving and Sustaining Open Defecation Free Communities: Learning from East Java. Research Brief. Water and Sanitation Program. World Bank. Accessed October 1, 2013 at http://www.wsp.org/sites/wsp.org/files/publications/WSP-Factors-Achieving-ODF-East-Java.pdf

Musyoki, S.M. (2010) A note for trainers, facilitators and those commissioning CLTS training. In Tales of shit: Community-Led Total Sanitation in Africa, vol 61. Participatory Learning and Action (PLA), London. Accessed October 1, 2013 at http://www.communityledtotalsanitation.org/resource/tales-shit-community-led-totalsanitation-africa-pla-61 
North, D, C.1990: Institutions, Institutional Change and Economic Performance. ISBN: 9780521397346: Cambridge University Press

Ostrom V. and Ostrom.E. 1971: Public Choice: A Different Approach to the Study of Public Administration. Public Administration Review, 31 (2), 203-216

Ostrom, E. 2005 Understanding Institutional Diversity. Princeton University Press. ISBN: 9780691122380

Overseas Development Institute (2011). Analysing the governance and political economy of water and sanitation service delivery. Working Paper 334. By Daniel Harris, Michelle Kooy and Lindsey Jones, ,August 2011.

Peal, A., Evans, B. \& van der Voorden, C. (2010). Hygiene and Sanitation Software. An overview of approaches. Water Supply and Sanitation Collaborative Council, Geneva, Switzerland. Accessed October 1, 2013 at http://www.wsscc.org/sites/default/files/publications/wsscc hygiene and sanitation software 2010.pdf

Pedi, D., Kov P., \& Smets, S. (2012). Sanitation Marketing Lessons from Cambodia: A Market-Based Approach to Delivering Sanitation. Water and Sanitation Program. World Bank. Accessed October 1, 2013 at https://www.wsp.org/sites/wsp.org/files/publications/WSP-Sanitation-marketing-lessons-Cambodia-Marketbased-delivering-Sanitation.pdf

Pelto, P. (1994). The qualitative and quantitative mix in researching on hygienic practices. In Cairncross, S. ,\& Kochar, V. (Eds.), Studying Hygiene Behaviour: Methods, Issues and Experiences. Sage Publications India Limited, New Delhi. ISBN: 81-7036-387-X

Perez E., Cardosi, J., Coombes, Y., Devine, J., Grossman, A., Kullmann, C., Kumar, C.A, Mukherjee, N.,Prakash, M., Robiarto, A., Setiawan, D., Singh, U., \& Wartono, D. (2012). What Does It Take to Scale Up Rural Sanitation? Working Paper, Water and Sanitation Program, July 2012. Accessed October 1, 2013 at http://www.wsp.org/sites/wsp.org/files/publications/WSP-What-does-it-take-to-scale-up-rural-sanitation.pdf

Robinson, A. (2011). Scaling Up Rural Sanitation in Tanzania. Enabling Environment Endline Assessment. Working Paper, Water and Sanitation Program, December 2011. Accessed October 1, 2013 at http://www.wsp.org/sites/wsp.org/files/publications/WSP-Tanzania-Enabling-Environment-Endline.pdf

Samson, K. (2006) Government engagement with non-state providers of water and sanitation services. Public Admin. Dev. 26, 207-217.

Shah, A.(1998). Balance, accountability, and responsiveness: lessons about decentralization. Policy research Working Paper 2021. The World Bank Operations Evaluation Department. Country and Regional Evaluation Division, Washington, DC.

Søreide, T., Tostensen, A., \& Skage, I.A. (2012). Hunting for Per Diem: The Uses and Abuses of Travel Compensation in Three Developing Countries. Report 2/2012. Norwegian Agency for Development Cooperation (Norad), March 2012.

Steffensen, J., Tidemand, P., \& Mwaimpopo, E. (2004). A Comparative Analysis of Decentralisation in Kenya, Tanzania and Uganda. Country Study-Tanzania. Accessed October 1, 2013 at http://www.dege.biz/FINALSYNTHESISREPORTnovember.pdf

Swatuk, L.A. (2008). A political economy of water in Southern Africa. Water Alternatives, 1(1), 24-47.

Therkildsen, O., \& Tidemand, P. (2008). Staff management and organisational performance in Tanzania and Uganda: public service perspectives. Danish Institute for International Studies, Copenhagen. 
Trémolet, S., Kolsky, P., \& Perez, E. (2010). Financing On-Site Sanitation for the Poor. A Six Country Comparative Review and Analysis. Technical Paper, Water and Sanitation Program, January2010. Accessed October 1, 2013 at http://www.wsp.org/sites/wsp.org/files/publications/financing analysis.pdf

UNICEF (2013). Community-Led Total Sanitation in East Asia and Pacific Progress, Lessons and Directions. Review of the status of community-led sanitation implementation in East Asia and Pacific. March 2013. Accessed October 1, 2013 at http://www.unicef.org/eapro/Community_Led_Total_Sanitation.pdf

Venugopal, V., \& Yilmaz, S.(2010). Decentralization in Tanzania: an assessment of local government discretion and accountability. Public Admin. Dev., 30, 215-231.

Water and Sanitation Program (2011). The Political economy of Sanitation: How can we increase investment and improve service for the poor? Operational experiences from case studies in Brazil, India, Indonesia, and Senegal. Technical Paper, Water and Sanitation Program, February 2011. Accessed October 1, 2013 at http://www.wsp.org/sites/wsp.org/files/publications/WSP-Political-Economy-of-Sanitation.pdf

WHO \& UNICEF (2012). Progress on sanitation and drinking-water. 2012Update. Joint Monitoring Programme for Water Supply and Sanitation. World Health Organization Press. Geneva.

WHO \& UNICEF, no date. The sanitation and drinking-water ladders. Accessed October 1, 2013 at http://www.wssinfo.org/definitions-methods/watsan-ladder/

World Health Organization (2012). UN-water global annual assessment of sanitation and drinking-water (GLAAS) 2012:the challenge of extending and sustaining services. World Health Organization Press. Geneva.

Wunsch J. 2001. Decentralization, local governance and 'recentralization' in Africa. Public Administration and Development 21(4), 277-288. 